\title{
Biotic Resistance Against Invasive Macroalgae: The Role of Omnivorous Sparid Fishes in the Herbivory on Caulerpa Cylindracea
}

Jorge Santamaría ( $\square$ jorge.santamaria@udg.edu )

Marine Resources and Biodiversity Research Group (GRMAR), Institute of Aquatic Ecology, University of Girona https://orcid.org/0000-0003-4425-6297

\section{Fiona Tomas}

Department of Marine Ecology and Resources, Instituto Mediterráneo de Estudios Avanzados (IMEDEA)

\section{Enric Ballesteros}

Center for Advanced Studies of Blanes: Centro de Estudios Avanzados de Blanes

\section{Emma Cebrian}

Center for Advanced Studies of Blanes: Centro de Estudios Avanzados de Blanes

\section{Research Article}

Keywords: fish-alga interactions, herbivory, biotic resistance, marine temperate systems, Sparidae, Caulerpa cylindracea

Posted Date: March 1st, 2021

DOI: https://doi.org/10.21203/rs.3.rs-194752/v1

License: (1) This work is licensed under a Creative Commons Attribution 4.0 International License. Read Full License 


\section{Biotic resistance against invasive macroalgae: the role of omnivorous sparid fishes in the herbivory on Caulerpa cylindracea}

Jorge Santamaría ${ }^{1}$, Fiona Tomas ${ }^{2,3}$, Enric Ballesteros $^{4}$, Emma Cebrian $^{1,4}$

${ }^{1}$ Marine Resources and Biodiversity Research Group (GRMAR), Institute of Aquatic Ecology, University of Girona, Girona, Catalonia, Spain

${ }^{2}$ Department of Marine Ecology and Resources - Instituto Mediterráneo de Estudios Avanzados (IMEDEA), Universitat de les Illes Balears (UIB) - Consejo Superior de Investigaciones Científicas (CSIC), Esporles, Balearic Islands, Spain

${ }^{3}$ Department of Fisheries and Wildlife, Oregon State University, Corvallis, Oregon, United States of America

${ }^{4}$ Centre d'Estudis Avançats de Blanes, Consejo Superior de Investigaciones Científicas (CEAB-CSIC), Blanes, Catalonia, Spain

Corresponding Author:

Jorge Santamaría ${ }^{1}$

Email address: jorge.santamaria@udg.edu

ORCID numbers of the authors:

Jorge Santamaría: 0000-0003-4425-6297

Fiona Tomas: 0000-0001-8682-2504

Enric Ballesteros: 0000-0001-5532-5337

Emma Cebrian: 0000-0001-7588-0135 


\section{Abstract}

2 Herbivory has long been considered an important component of biotic resistance

3 against macroalgae invasions in marine habitats. However, most of the studies on

4 herbivory of invasive algae refer only to consumption by strictly herbivorous

5 organisms, whereas consumption by omnivorous organisms has been largely

6 ignored and rarely quantified. In this study, we assess whether the commonest

7 omnivorous sparid species in the Mediterranean Sea are consuming the highly

8 invasive alga, Caulerpa cylindracea, and determine its importance in their diet and

9 their electivity towards it as a source of food. Our results confirm that three of the

10 four fish species we studied do, in fact, consume C. cylindracea, but in most cases,

11 the importance of $C$. cylindracea in the diet was low. Indeed, the low electivity

12 values confirm that all four fish species avoid feeding on the invasive alga and that

13 it is probably consumed accidentally. However, despite animals and detritus being

14 the main food for these sea bream species, several individual specimens were

15 found to have consumed high amounts of $C$. cylindracea. This suggests a potential

16 role that these fish species may play in controlling, to some extent, the abundance

17 of the invader. We suggest that herbivory by omnivorous fish might complement

18 the higher impact exerted by the strict herbivores, and together, they might

19 contribute to the overall biotic resistance against the invader.

20 Keywords: fish-alga interactions, herbivory, biotic resistance, marine temperate

21 systems, Sparidae, Caulerpa cylindracea 


\section{Declarations}

\section{Funding}

24 Funding for this Project was obtained from the Spanish Ministry Project ANIMA

25 (CGL2016-76341-R, MINECO/FEDER, UE), the Spanish Autonomous Organism of 26 National Parks through the project BIGPARK (project 2017-2462) and the Padi 27 Foundation to F.T. (CGA App \#: 5134). J.S. has received funding from "La Caixa" 28 Foundation (ID 100010434), under agreement LCF/BQ/DE17/11600001.

\section{Conflicts of interest}

30 All authors certify that they have no conflicts of interest to declare that are relevant to

31 the content of this article

\section{Data availability}

33 The raw data generated and analyzed for this study is available from the

34 corresponding author upon request.

\section{Authors' contribution}

36 F.T. and E.C. conceived the ideas and the experimental design; F.T., E.B. and E.C.

37 collected the data; J.S., F.T., E.B. and E.C. analyzed the data; J.S. and E.C. drafted the 38 manuscript and all the authors contributed substantially to revisions and accepted the 39 final version before submission. 


\section{Introduction}

In the marine environment, invasive species pose a growing threat to native ecosystems (Bax et al. 2003) and the problem is expected to continue to worsen in the near future, due mainly to ongoing intensification in shipping traffic and climate change (Stachowicz et al. 2002; Seebens et al. 2013). In these systems, macroalgae are one of the most successful and conspicuous groups (Schaffelke et al. 2006), with at least 346 identified taxa worldwide (Thomsen et al. 2016). Marine invasive macroalgae can contribute to the homogenization of marine habitats, affecting the structure of native assemblages by reducing both native species biomass and overall assemblage diversity (Williams and Smith 2007; Schaffelke and Hewitt 2008; Thomsen et al. 2009, 2016). Furthermore, once established, they are extremely difficult to eradicate (Anderson 2007). However, various mechanisms and features - both biotic and abiotic - in the receiving community and habitat, can reduce invasive success and affect the establishment and persistence of marine algae (Dunstan and Johnson 2007; Catford et al. 2009; Thomsen et al. 2009; Kimbro et al. 2013; Papacostas et al. 2017). Among the biotic factors, herbivory has long been considered as a potential biotic resistance mechanism and many studies have been conducted worldwide to assess the role of this mechanism on invasive macroalgae success (references within Kimbro et al. 2013 and Papacostas et al. 2017). Until now, the role of herbivory as a limiting factor for macroalgae invasion has dealt mainly with strictly herbivorous species (e.g., Ruitton et al. 2006, Wikström et al. 2006, Lyons and Scheibling 2008, Britton-Simmons et al. 2011, Cebrian et al. 2011, Tomas et al. 2011b, Hammann et al. 2013), with contrasting results depending on the assemblage and the invasive species considered (Boudouresque et al. 1996; Trowbridge and Todd 1999; Scheibling and Anthony 2001; 
64 Stimson et al. 2001; Davis et al. 2005; Wikström et al. 2006; Monteiro et al. 2009;

65 Steinarsdóttir et al. 2009; Tomas et al. 2011b, a; Nejrup et al. 2012).

67 (Williams and Smith 2007; Thomsen et al. 2016) and the number of potential invaders 68 arriving is on the rise due to the intensification of marine traffic and to the widening of 69 the Suez Canal (Katsanevakis et al. 2013; Galil et al. 2017). In the Mediterranean Sea, 70 the most successful and widespread invasive macroalga is Caulerpa cylindracea (Klein and Verlaque 2008; Katsanevakis et al. 2016), a green alga native of the Southwestern coast of Australia that was first detected in Mediterranean waters in Libya in 1990 (Nizamuddin 1991). Since then, it has colonized marine communities throughout the entire Mediterranean basin (Piazzi et al. 2005; Klein and Verlaque 2008), where it can exert strong detrimental effects on native communities (Piazzi et al. 2001; Klein and Verlaque 2008; Bulleri et al. 2016, 2017). However, despite its rampant success, several Caulerpa cylindracea meadows have suffered sudden steep declines in abundance (Klein and Verlaque 2008; García et al. 2016), which may indicate the existence of certain resistance mechanisms against this invasive species. Among these, herbivory on C. cylindracea has been described and assessed, although mainly in relation to the strictly herbivorous species present in the Mediterranean Sea, such as the fishes, Sarpa salpa and Siganus luridus (Azzurro et al. 2004; Ruitton et al. 2006; Tomas et al. 2011b), and the sea urchins, Paracentrotus lividus, Sphaerechinus granularis and Arbacia lixula (Ruitton et al. 2006; Bulleri et al. 2009; Cebrian et al. 2011; Tomas et al. 2011a). In fact, S. salpa and P. lividus are keystone herbivores in the Mediterranean, and both show a preference towards the invasive alga (Tomas et al. 2011a, b).

87 Nevertheless, there are omnivorous fish species, such as Diplodus sargus, Boops boops, 
89 before (Ruitton et al. 2006; Box et al. 2009; Terlizzi et al. 2011). Unfortunately, 90 information is scarce on whether C. cylindracea is a common food source for these fish 91 species, or whether these, and other omnivorous fish actively elect to feed on it. Since

92 some of these species are the dominant fish in the shallow, infralittoral rocky habitats in 93 the Mediterranean Sea (García-Rubies 1997; Sala and Ballesteros 1997), information on 94 their consumption of $C$. cylindracea is needed to determine whether they can play a role 95 in the biotic resistance to the invasive process - by contributing to the control of $C$. cylindracea abundance - and to determine how important such a role might be.

In this study, the diets of four omnivorous sea bream species (Sparidae) were examined in order to determine (i) whether they feed on the invasive alga $C$. cylindracea, (ii) whether C. cylindracea is important in their diet and (iii) whether they actively select or avoid C. cylindracea as a source of food

\section{$101 \quad$ Materials and methods}

\section{Study area}

The samples for this study were collected in the Cabrera Archipelago National

104 Park (North-Western Mediterranean Sea; 39¹2’21” N, 258’44” E) (Fig. 1) in 2008. 105 This marine-terrestrial protected area was established in 1991 and since then it has 106 maintained an exceptional conservation status for its marine habitats (Sala et al. 2012; 107 Coll et al. 2013; Guidetti et al. 2014). Caulerpa cylindracea was recorded for the first 108 time in the National Park in 2003 at a depth of 30-35 m and since then its distribution 109 has expanded to cover most of its benthic communities at depths of between 0 and $65 \mathrm{~m}$ 110 (Cebrian and Ballesteros 2009). 


\section{Analysis of Caulerpa cylindracea consumption}

112 To determine whether non-strictly herbivorous fish species consume $C$.

113 cylindracea, specimens for this study were captured by long-lines and gillnets on

114 several occasions during June and July 2008, at different sites across the Archipelago,

115 close to the localities of Ses Rates and the Foradada Islet (Fig. 1). The main fishes

116 targeted belong to the family Sparidae: white sea bream (Diplodus sargus), annular sea

117 bream (Diplodus annularis), two-banded sea bream (Diplodus vulgaris) and black sea

118 bream (Spondyliosoma cantharus). These species were chosen because they are

119 common representatives of the fish assemblages found in the Western Mediterranean,

120 they are not herbivorous but can feed on macroalgae (Sala and Ballesteros 1997) and

121 some of them have been observed feeding on C. cylindracea before (Box et al. 2009;

122 Terlizzi et al. 2011). These four species have different abundances within the National

123 Park, the least abundant of them being S. cantharus, with 0.2 individuals per $250 \mathrm{~m}^{2}$,

124 and the most abundant being D. vulgaris, with up to 6 individuals per $250 \mathrm{~m}^{2}$ (Reñones 125 et al. 1997).

126 The long-lines and gillnets, two gears commonly used in artisanal fishing, were

127 deployed at depths of between 10 and $30 \mathrm{~m}$. Every time a targeted fish species was

128 hauled in, it was gutted and its stomach was stored and preserved in buffered $4 \%$

129 formaldehyde-seawater solution for later analysis of its content. Once in the laboratory,

130 the species composition and abundance of the food items in each fish stomach was

131 determined under a Stemi 2000-C stereomicroscope (Carl Zeiss, Berlin, Germany). The

132 content of each stomach was spread onto a reticulated Petri dish and the food items

133 were classified to the lowest taxonomic level possible. Both surface area and weight

134 measurements can reflect the dietary contribution of food items (Hyslop 1980;

135 Macdonald and Green 1983), but in this case, and to avoid biases that could be derived 
136 from the small quantities present in the stomach contents, surface area measurements

137 were preferred over weight measurements to quantify the dietary contribution of each

138 food item. As such, the abundance of a particular food item was estimated as the

139 percentage cover on the reticulated fields of the Petri dish in relation to the cover of the

140 whole stomach content. When a species had a minimal presence and its cover could not

141 be determined, a value of $0.1 \%$ of relative coverage was assigned.

142 When calculating the relative measures of prey quantity (RMPQ), and to avoid 143 possible biases caused by each prey (or food item) being identified to different

144 taxonomic levels, the stomach contents were divided into the following five prey

145 categories: Caulerpa cylindracea, Algal content, Plants, Animal content and

146 Detritus. Subsequently, for each fish species, the percentage frequency of occurrence of

147 each prey category $\left(\mathrm{FO}_{\mathrm{i}}\right)$ was calculated as:

$$
F O_{i}=\left(S_{i} S_{t}\right) \cdot 100
$$

149 where $S_{i}$ is the number of stomachs containing the prey category and $S_{t}$ is the total 150 number of stomachs analyzed for that particular fish species. The $\mathrm{FO}_{\mathrm{i}}$ value is a measure 151 of the consistency with which a species selects a given prey category and was used to 152 calculate two dietary indices that allow to compare the diets between species: the 153 Combined Index $\left(\mathrm{Q}_{\mathrm{i}}\right)$ and the Geometric Index of Importance (GII).

154 The combined index, $\mathrm{Q}_{\mathrm{i}}$, was chosen to assess the relative importance of each 155 prey category for each fish species. This index standardizes the abundance of each 156 category and increases the importance of frequent smaller items while reducing the

157 importance of occasional larger items (Nilssen et al. 2019). It was calculated as:

$$
Q_{i}=\frac{V_{i} \cdot F O_{i}}{\sum_{i=1}^{m}\left(V_{i} \cdot F O_{i}\right)}
$$


where $V_{i}$ refers to the percentage surface of a prey category, $F O_{i}$ refers to the frequency

160 of occurrence of the given prey category, and $m$ is the total number of prey categories.

161 On the other hand, the Geometric Index of Importance, GII, represents the 162 degree of feeding specialization on a particular prey type (Assis 1996; Preti et al. 2001) 163 and allows us to classify the prey categories as: "Preferential prey", "Secondary prey" 164 and "Occasional prey" in relation to the larger discontinuities in a decreasing sequence 165 of values (Assis 1996; Tripp-Valdez et al. 2015). It was calculated as:

$$
G I I_{j}=\frac{\sum_{i=1}^{n}\left(V_{i}+F O_{i}\right)}{\sqrt{2}}
$$
Finally, the degree to which the four fish species tend to elect to feed on $C$. cylindracea, was assessed by Ivlev's electivity Index (E) (Ivlev 1961). This Index was determined by:

$$
E=\frac{\left(d_{i}-a_{1}\right)}{\left(d_{i}+a_{i}\right)}
$$

171 where $\mathrm{d}_{\mathrm{i}}=\%$ of $C$. cylindracea in the stomach content and $\mathrm{a}_{\mathrm{i}}=\%$ of $C$. cylindracea 172 available in the environment (see following section). The values of the Ivlev's Index (E) 173 can range from -1 (complete avoidance of the food item) to +1 (exclusive selection of 174 the item), with positive values indicating that the food item is selected and eaten more 175 than it is encountered by chance in the environment (Ivlev 1961).

\section{Assessment of the abundance of Caulerpa cylindracea in the community}

177 The abundance of $C$. cylindracea at the sampling sites where the fish specimens 178 were captured was assessed by means of scuba diving. At each site, a perpendicular 179 transect to shore was done, at depths of 10 to $30 \mathrm{~m}$, so as to cover the same bathymetric 180 range as that of the fishing gear used to collect fish samples. To estimate C. cylindracea 181 abundance, a total of thirty quadrats measuring $25 \times 25 \mathrm{~cm}^{2}$ were randomly positioned 
182 within each 10 m-depth range (total of 90 quadrats per sampling site). These quadrats

183 were divided into 25 subquadrats of $5 \times 5 \mathrm{~cm}^{2}$ and the number of subquadrats where $C$.

184 cylindracea appeared was used as the unit of abundance (Sala and Ballesteros 1997;

185 Cebrian and Ballesteros 2004; Sant et al. 2017). Subsequently, the average $C$.

186 cylindracea abundance for the study area was calculated and this value was used in the

187 calculation of the Ivlev's electivity Index.

$188 \quad \underline{\text { Statistical analyses }}$

189 Differences in the specific composition of stomach contents between fish species

190 were assessed through multivariate techniques such as non-metric multi-dimensional

191 scaling plots (NMDS plots), analysis of similarities (ANOSIM) and similarity

192 percentage analysis (SIMPER). All of these techniques were performed within the

193 vegan package (Oksanen et al. 2018) in the $\mathrm{R}$ environment (R Core Team 2018). First,

194 in order to visualize and represent stomach content composition, an NMDS (Clarke and

195 Warwick 1994; Cox and Cox 2000) based on the Bray-Curtis dissimilarity matrix of the

196 square-root transformed data was plotted and the most important species that determine

197 the least stressful ordination were detected using the envfit function within the vegan

198 package. Then, the statistical differences in the food items consumed by the fish species

199 were assessed using ANOSIM (Clarke 1993), applied to the Bray-Curtis dissimilarity

200 matrix, with fish species as a fixed factor. Additionally, to perform the pairwise

201 comparison between the fish species, a pairwise ANOSIM was performed by modifying

202 the pairwise.adonis function (https://github.com/pmartinezarbizu/pairwiseAdonis) and

203 the R-values obtained were used as an indication of diet similarity, with values near 1

204 indicating separation in diet composition and values near 0 indicating diet similarity

205 (Rogers et al. 2012). Finally, a SIMPER analysis based on the Bray-Curtis dissimilarity 
206 index was used to assess the relative contribution of each food item to the overall 207 differences between fish species diets.

\section{Results and discussion}

209 During the sampling events, a total of 93 fishes were captured, with D. sargus 210 being the most abundant (51 individuals) and $D$. annularis the scarcest (7 individuals).

211 All the stomachs examined contained ingested material of some kind, which, as a 212 whole, was composed of a high diversity of taxonomic groups, with 73 different prey 213 items identified, 32 of them to the species level (Table S1). Differences in stomach 214 content were observed between species in terms of the dominant prey categories, 215 although detritus and animal content were certainly prominent in all four species (Table 216 1). In this sense, the Combined Index (Qi) and the Geometric Index of Importance 217 (GII), identified the category "Detritus" as the preferential food item for S. cantharus, 218 while the category "Animal content" was the preferential prey for the other three fish 219 species (Figs. 2 and 3). These findings agree with previous studies in which the 220 predominant food type in the diet of these sea breams was observed to be animals or 221 detritus (Sala and Ballesteros 1997; Gonçalves and Erzini 1998; Pita et al. 2002; Box et 222 al. 2009; Terlizzi et al. 2011; Felline et al. 2012, 2017), although they have also been 223 found to feed on considerable amounts of algae (Sala and Ballesteros 1997; Pita et al. 224 2002; Box et al. 2009; Terlizzi et al. 2011; Felline et al. 2012, 2017). In our case, all the 225 fish species studied had consumed algae and seagrasses; in particular, the stomach 226 contents of both $D$. sargus and $D$. annularis were rich in algae, with values of around $22718 \%$ and $30 \%$ respectively (Table 1), which are higher than previously reported results 228 for sea breams (Sala and Ballesteros 1997; Sánchez-Jerez et al. 2002; Box et al. 2009). 

ordination suggests that there might be some overlap between diets (Fig. 4); however, according to the ANOSIM, the stomach content composition was significantly different

232 between fish species (p-value $<0.05$; Table 2), with two exceptions: D. sargus $-D$. 233 vulgaris and D. sargus $-D$. annularis (p-value $>0.05$; Table 2 ). In this sense, the 234 greatest dissimilarities in diet were between D. annularis and $S$. cantharus $(\mathrm{R}=0.63)$ and 235 between $D$. vulgaris and $S$. cantharus $(\mathrm{R}=0.47)$ (Table 2$)$, which may be due to the fact that the diet of $S$. cantharus is more homogeneous than those of the other species, being dominated by detritus rather than animal items (Fig. 4). Actually, the SIMPER analysis identified the food item 'organic detritus' as the biggest contributor to the diet 239 dissimilarities between the four fish species, with values of between $19 \%$ and $40 \%$ 240 (Table 3). Regarding the consumption of $C$. cylindracea, three species, namely $D$. 242 annularis, D. sargus and S. cantharus, were found to have consumed it. Although both 243 D. sargus and S. cantharus had already been observed feeding on C. cylindracea (Box 244 et al. 2009; Terlizzi et al. 2011; Felline et al. 2012), this is the first evidence of such 245 behavior in D. annularis. Furthermore, while only $41 \%$ and $45 \%$ of the $S$. cantharus and D. sargus specimens had consumed C. cylindracea, the figure for D. annularis 247 specimens was around $85 \%$, which strongly suggests that this invasive alga is a 248 recurrent item in the diet of D. annularis in the Cabrera Archipelago. Unfortunately, it 249 must be stressed that only seven specimens of $D$. annularis were captured and 250 examined, so a higher sample size is needed to draw more robust conclusions on the 251 importance of $C$. cylindracea in the diet of D. annularis. In contrast with the other three species, there was no evidence that the D. vulgaris specimens $(\mathrm{n}=13)$ collected at the

253 Cabrera Archipelago for this study had consumed C. cylindracea, despite the fact that 
254 D. vulgaris has previously been observed feeding on $C$. cylindracea (Felline et al. 255 2017).

Overall, although $C$. cylindracea was found in the diet of three of the four sea

257 bream species, its contribution to the total stomach content was generally low. The 258 biggest consumer was $D$. annularis, with nearly $26 \%$ of its total stomach content 259 corresponding to $C$. cylindracea (Table 1). In fact, both dietary indexes, $\mathrm{Q}_{i}$ and GII, 260 classified this food item as a preferential prey item for D. annularis as it was the second most common prey category in their stomachs and had importance values similar to 262 those of the most common prey category, which was animal content (Figs. 2 and 3). 263 Furthermore, the SIMPER analysis identified $C$. cylindracea as the second most 264 important food item in terms of explaining the diet dissimilarities between D. annularis and the other fish species (Table 3). On the other hand, C. cylindracea was classified as an occasional food item for both D. sargus and S. cantharus, but while the algae content in the stomachs of $S$. cantharus was only around $7 \%$, it is worth noting that most of it $(\approx 74 \%$ ) corresponded to $C$. cylindracea (Table 1$)$. These findings are in agreement with 269 the study by Box et al. (2009), where C. cylindracea was not the main carbon and 270 nitrogen source for $S$. cantharus. On the other hand, in contrast with our results, 271 previous studies have shown $C$. cylindracea to be the most important prey item for $D$. 272 sargus and the second-most for S. cantharus (Terlizzi et al. 2011; Felline et al. 2012, 273 2017). Although these differences could be due to different sampling methodologies or 274 to the site-specific characteristics of the study areas, it is also possible that they are the 275 result of seasonal dynamics in the abundance of the invasive alga. Our samples were 276 taken in early to mid summer, whereas the samples in the studies that found higher 277 percentages of $C$. cylindracea in the stomach contents, were taken at the end of summer 278 and the beginning of autumn (Terlizzi et al. 2011; Felline et al. 2012, 2017), which 
corresponds to the season when $C$. cylindracea achieves its peak in abundance and 280 growth (Piazzi et al. 2001; Ruitton et al. 2005; Klein and Verlaque 2008).

Despite the significant contribution of $C$. cylindracea to the diet of D. annularis, and despite the fact that it was found to be the dominant algae species in the benthic communities (with mean coverage values close to 55\%), the negative values obtained in

284 the Ivlev Electivity Index suggest that all four of the fish species studied tend to avoid 285 feeding on the invasive alga (Table 4). However, it is important to consider that, as is the case with consumption, electivity towards $C$. cylindracea may also change in relation to the season. Indeed, this has already been observed in the strictly herbivorous fish, Sarpa salpa (Tomas et al. 2011b). It may therefore be important to assess whether the consumption of $C$. cylindracea by the four sea bream species studied here, and their electivity towards it, is related to C. cylindracea's seasonality in the Mediterranean Sea and whether it increases towards autumn when the invasive alga is the dominant component of many benthic assemblages. In fact, it was at the beginning of autumn when the stomach contents of S. salpa were found to be dominated by $C$. cylindracea and when the highest grazing activity on the invasive alga was observed (Ruitton et al. 2005, 2006; Tomas et al. 2011b).

Despite the general avoidance of Caulerpa cylindracea, high amounts of it were

297 found in the stomach contents of some individuals. This suggests that it is probably 298 consumed accidentally when the fish are trying to feed on other prey living within the 299 dense meadows of $C$. cylindracea. In fact, polychaetes, mollusks and decapods - which 300 are the preferential prey for most of the sea breams studied (Bauchot and Hureau 1986; 301 Sala and Ballesteros 1997; Gonçalves and Erzini 1998; Pita et al. 2002; Leitão et al. 302 2007) - have been found to be very abundant under the stolons of $C$. cylindracea 303 (Carriglio et al. 2003; Galil 2007; Box 2008; Klein and Verlaque 2008). Furthermore, 
304 the suggestion that consumption of the alga is accidental is also supported by the low 305 assimilation of $C$. cylindracea in the stomach contents, as in most cases it was found 306 intact and undigested (Fig. 5). However, taking into account that some of the sea breams 307 considered here have small home ranges and show strong site fidelity (D'Anna et al. 308 2011; March et al. 2011; Alós et al. 2012; Di Lorenzo et al. 2014), it cannot be ruled out 309 that they might also be forced to feed on $C$. cylindracea in heavily colonized areas 310 (Felline et al. 2014), and this may have a negative impact on the physiology of the fish. 311 Actually, previous evidence relate $C$. cylindracea consumption to a decrease in certain 312 essential fatty acids in fish tissues and liver (Felline et al. 2014), an increase in the 313 levels of antioxidants and in pro-oxidant effects (Box et al. 2009; Terlizzi et al. 2011; 314 Felline et al. 2012), a decrease in the condition factor (Terlizzi et al. 2011) and a 315 decrease in the gonadosomatic-index (Felline et al. 2012), all of which may negatively affect the nutritional status and the health of the fish. It is not yet clear what causes 317 these physiological responses, although they could be caused by the accumulation of 318 some of the compounds produced by $C$. cylindracea, such as caulerpenyne, a toxic, 319 secondary metabolite that has herbivore-deterrent properties (Paul et al. 2007). 320 However, considering that Caulerpa prolifera, a native species in the Mediterranean 321 Sea, has much higher caulerpenyne concentrations than C. cylindracea (Box et al. 2010) 322 and that sea breams can often consume the native Caulerpa species (Table S1) 323 (Chaouch et al. 2013, 2014; Marco-Méndez et al. 2017), it is likely that the fish have 324 developed a certain tolerance to the toxic metabolites, as other herbivores have done 325 (Cornell and Hawkins 2003) and they may also have effective detoxification pathways. 326 In any case, more studies are needed to understand the possible long-term consequences 327 of $C$. cylindracea consumption on the health of fish assemblages and whether these 328 consequences could propagate throughout the food-web, potentially affecting the 
329 functioning of the ecosystem through cascading effects. Furthermore, long-term studies 330 that determine whether the consumption of $C$. cylindracea changes with time since 331 invasion and whether the physiological consequences of $C$. cylindracea consumption 332 decrease with time, might provide important information on the potential adaptation of 333 sea breams to the consumption of this invasive alga.

334 Overall, our findings confirm that the invasion of Caulerpa cylindracea in the 335 Mediterranean Sea is not influencing the foraging habits and diets of the strictly 336 herbivorous organisms (Azzurro et al. 2004; Ruitton et al. 2006; Cebrian et al. 2011; 337 Tomas et al. 2011b, a), but also those of omnivorous fish species (Box et al. 2009; 338 Terlizzi et al. 2011; Felline et al. 2014). In this sense, our assessment of C. cylindracea 339 consumption by omnivorous species (i.e. non-strict herbivores) is noteworthy since 340 most of the previous research into the effects of herbivory on invasive algae has focused 341 only on the strict herbivores (e.g., Scheibling and Anthony 2001, Davis et al. 2005, 342 Wikström et al. 2006, Ruitton et al. 2006, Lyons and Scheibling 2008, Vermeij et al. 343 2009, Britton-Simmons et al. 2011, Cebrian et al. 2011, Tomas et al. 2011b, 2011a, 344 Nejrup et al. 2012, Hammann et al. 2013). Such studies have pointed out the potential 345 contribution of some of these herbivores to limiting the abundance of invasive algae 346 (Stimson et al. 2001; Lyons and Scheibling 2008; Britton-Simmons et al. 2011; Tomas 347 et al. 2011b), but our findings suggest that a similar, albeit less important contribution 348 by non-strict herbivores should also be considered. In fact, although it appears that the 349 four omnivorous species studied here tended to avoid C. cylindracea, the role of these 350 fish in the biotic control of $C$. cylindracea cannot be disregarded since high amounts of 351 the alga were found in the stomachs of some individuals and these fish do, in fact, 352 dominate the shallow rocky infralittoral habitats in the Mediterranean Sea (García353 Rubies 1997; Sala and Ballesteros 1997). As such, it is quite likely that the lower 
354 impact exerted by the omnivorous fish can complement the higher impact exerted by the

355 strictly herbivorous organisms and that, taken together, they might significantly reduce

356 the abundance of $C$. cylindracea in shallow habitats. Finally, considering that sea

357 breams are highly targeted by fisheries and have already suffered important declines in 358 the Mediterranean basin (Sala et al. 1998; Coll et al. 2004; Sala 2004; Morales-Nin et 359 al. 2005; Guidetti 2006; Lloret et al. 2008), places that foster their recovery, such as 360 well-enforced marine protected areas (MPAs) (Mosquera et al. 2000; Micheli et al. 361 2005; Claudet et al. 2006; Guidetti and Sala 2007; Guidetti et al. 2008, 2014; Sala et al. 362 2012; Coll et al. 2013), might also foster the complementary biotic resistance of native 363 assemblages against the invasion of C. cylindracea.

\section{Acknowledgements}

365 The authors would like to thank Xisco Riera, Biel Morey and Oliver Navarro for help 366 during the fishing campaigns, Paula Molina for help with laboratory work, the 367 authorities and staff of the Cabrera Archipelago National Park for sampling permissions 368 and logistical support and the Directorate General for Fisheries and Marine Resources 369 of the Balearic Islands Government for helping with fishing logistics. This is a 370 contribution from the Consolidated Research Group "Medrecover; 371 www.medrecover.org", SGR2017-1521 (Catalan Government).

\section{References}

373 Alós J, Cabanellas-Reboredo M, March D (2012) Spatial and temporal patterns in the movement of adult two-banded sea bream Diplodus vulgaris (Saint-Hilaire, 1817). Fish Res 115-116:82-88. https://doi.org/10.1016/j.fishres.2011.11.025 
378 Assis CA (1996) A generalised index for stomach contents analysis in fish. Sci Mar $60: 385-389$

Azzurro E, Fanelli E, Andaloro F (2004) Preliminary data on feeding habits of dusky spinefoot Siganus luridus in the Sicily Channel (central Mediterranean). Biol Mar Mediterr 11:145

383

384

385

Bauchot ML, Hureau JC (1986) Sparidae. In: Whitehead PJP, Bauchot ML, Hureau JC, et al. (eds) Fishes of the North-eastern Atlantic and the Mediterranean, Vol. 3. Paris: UNESCO, pp 883-907

Bax N, Williamson A, Aguero M, et al (2003) Marine invasive alien species: A threat to global biodiversity. Mar Policy 27:313-323. https://doi.org/10.1016/S0308$597 X(03) 00041-1$

Boudouresque CF, Lemée R, Mari X, Meinesz A (1996) The invasive alga Caulerpa taxifolia is not a suitable diet for the sea urchin Paracentrotus lividus. Aquat Bot 53:245-250. https://doi.org/10.1016/0304-3770(96)01021-2

Box A (2008) Ecología de Caulerpales: fauna y biomarcadores. Ph D. Universitat de les Illes Balears

Box A, Deudero S, Sureda A, et al (2009) Diet and physiological responses of Spondyliosoma cantharus (Linnaeus, 1758) to the Caulerpa racemosa var. cylindracea invasion. J Exp Mar Bio Ecol 380:11-19. https://doi.org/10.1016/j.jembe.2009.08.010

Box A, Sureda A, Tauler P, et al (2010) Seasonality of caulerpenyne content in native Caulerpa prolifera and invasive C. taxifolia and C. racemosa var. cylindracea in the western Mediterranean Sea. Bot Mar 53:367-375. https://doi.org/10.1515/BOT.2010.034 
402 Britton-Simmons KH, Pister B, Sánchez I, Okamoto D (2011) Response of a native, 403 herbivorous snail to the introduced seaweed Sargassum muticum. Hydrobiologia 661:187-196. https://doi.org/10.1007/s10750-010-0523-1

405

406

407

408

409

410

411

412

413

414

415

416

417

418

419

420

421

422

423

424

425

426

Bulleri F, Badalamenti F, Iveša L, et al (2016) The effects of an invasive seaweed on native communities vary along a gradient of land-based human impacts. Peer $\mathbf{J}$ 4:e1795. https://doi.org/10.7717/peerj.1795

Bulleri F, Benedetti-Cecchi L, Ceccherelli G, Tamburello L (2017) A few is enough: A low cover of a non-native seaweed reduces the resilience of Mediterranean macroalgal stands to disturbances of varying extent. Biol Invasions 19:2291-2305. https://doi.org/10.1007/s10530-017-1442-0

Bulleri F, Tamburello L, Benedetti-Cecchi L (2009) Loss of consumers alters the effects of resident assemblages on the local spread of an introduced macroalga. Oikos 118:269-279. https://doi.org/10.1111/j.1600-0706.2008.16955.x

Carriglio D, Sandulli R, Deastis S, et al (2003) Caulerpa racemosa spread effects on the meiofauna of the Gulf of Taranto. Biol Mar Mediterr 10:509-511

Catford JA, Jansson R, Nilsson C (2009) Reducing redundancy in invasion ecology by integrating hypotheses into a single theoretical framework. Divers Distrib 15:2240. https://doi.org/10.1111/j.1472-4642.2008.00521.x

Cebrian E, Ballesteros E (2009) Temporal and spatial variability in shallow- and deepwater populations of the invasive Caulerpa racemosa var. cylindracea in the Western Mediterranean. Estuar Coast Shelf Sci 83:469-474. https://doi.org/10.1016/j.ecss.2009.04.026

Cebrian E, Ballesteros E (2004) Zonation patterns of benthic communities in an upwelling area from the Western Mediterranean (La Herradura, Alboran Sea). Sci Mar 68:69-84. https://doi.org/10.1016/0377-8398(88)90006-0 
427 Cebrian E, Ballesteros E, Linares C, Tomas F (2011) Do native herbivores provide 428 resistance to Mediterranean marine bioinvasions? A seaweed example. Biol 429 Invasions 13:1397-1408. https://doi.org/10.1007/s10530-010-9898-1

430 Chaouch H, Hamida OBABH, Ghorbel M, Jarboui O (2013) Diet composition and food 431 habits of Diplodus puntazzo (Sparidae) from the Gulf of Gabès (Central 432 Mediterranean). J Mar Biol Assoc United Kingdom 93:2257-2264. 433 https://doi.org/10.1017/S0025315413000805

434 Chaouch H, Hamida OBABH, Ghorbel M, Jarboui O (2014) Feeding habits of the 435 annular seabream, Diplodus annularis (Linnaeus, 1758) (Pisces: Sparidae), in the Gulf of Gabès (Central Mediterranean). Cah Biol Mar 55:13-19

437 Clarke KR (1993) Non parametric multivariate analyses of changes in community $438 \quad$ structure. Aust J Ecol 18:117-143. https://doi.org/10.1111/j.14429993.1993.tb00438.x

440 Clarke KR, Warwick RM (1994) Similarity-based testing for community pattern: The 441 two-way layout with no replication. Mar Biol 118:167-176. $442 \quad$ https://doi.org/10.1007/BF00699231

443 Claudet J, Pelletier D, Jouvenel JY, et al (2006) Assessing the effects of marine 444 protected area (MPA) on a reef fish assemblage in a northwestern Mediterranean marine reserve: identifying community-based indicators. Biol Conserv 130:349369. https://doi.org/10.1016/j.biocon.2005.12.030

447 Coll J, Garcia-Rubies A, Morey G, et al (2013) Using no-take marine reserves as a tool 448 for evaluating rocky-reef fish resources in the western Mediterranean. ICES J Mar Sci 70:578-590. https://doi.org/10.1038/srep04684

450 Coll J, Linde M, García-Rubies A, et al (2004) Spear fishing in the Balearic Islands (west central Mediterranean): species affected and catch evolution during the 

https://doi.org/10.1016/j.fishres.2004.05.004

454 Cornell H V., Hawkins BA (2003) Herbivore responses to plant secondary compounds: A test of phytochemical coevolution theory. Am Nat 161:507-522. https://doi.org/10.1086/368346

457 Cox TF, Cox MAA (2000) Multidimensional scaling. CRC press

458 D'Anna G, Giacalone VM, Pipitone C, Badalamenti F (2011) Movement pattern of 459 white seabream, Diplodus sargus (L., 1758) (Osteichthyes, Sparidae) acoustically tracked in an artificial reef area. Ital J Zool 78:255-263. https://doi.org/10.1080/11250000903464059

462 Davis AR, Benkendorff K, Ward DW (2005) Responses of common SE Australian herbivores to three suspected invasive Caulerpa spp. Mar Biol 146:859-868. https://doi.org/10.1007/s00227-004-1499-z

Di Lorenzo M, D’Anna G, Badalamenti F, et al (2014) Fitting the size of no-take zones to species movement patterns: A case study on a Mediterranean seabream. Mar Ecol Prog Ser 502:245-255. https://doi.org/10.3354/meps10723

468 Dunstan PK, Johnson CR (2007) Mechanisms of invasions: Can the recipient community influence invasion rates? Bot Mar 50:41-52. https://doi.org/10.1515/9783110211344

471 Felline S, Caricato R, Cutignano A, et al (2012) Subtle effects of biological invasions: 472 cellular and physiological responses of fish eating the exotic pest Caulerpa racemosa. PLoS One 7:e38763. https://doi.org/10.1371/journal.pone.0038763

474 Felline S, Mollo E, Cutignano A, et al (2017) Preliminary observations of caulerpin 475 accumulation from the invasive Caulerpa cylindracea in native Mediterranean fish species. Aquat Biol 26:27-31. https://doi.org/10.3354/ab00671 
477 Felline S, Mollo E, Ferramosca A, et al (2014) Can a marine pest reduce the nutritional 478 value of Mediterranean fish flesh? Mar Biol 161:1275-1283. $479 \quad$ https://doi.org/10.1007/s00227-014-2417-7

480 Galil B, Marchini A, Occhipinti-Ambrogi A, Ojaveer H (2017) The enlargement of the 481 Suez Canal-Erythraean introductions and management challenges. Manag Biol $482 \quad$ Invasions 8:141-152. https://doi.org/10.3391/mbi.2017.8.2.02

483 Galil BS (2007) Loss or gain? Invasive aliens and biodiversity in the Mediterranean 484 Sea. Mar Pollut Bull 55:314-322. https://doi.org/10.1016/j.marpolbul.2006.11.008

García-Rubies A (1997) Estudi ecològic de les poblacions de peixos litorals sobre 486 substrat rocós a la Mediterrània Occidental: efecte de la fondària, el substrat, l'estacionalitat i la protecció. Ph. D., Universitat de Barcelona

García M, Weitzmann B, Pinedo S, et al (2016) First report on the distribution and 489 impact of marine alien species in coastal benthic assemblages along the catalan coast. Handb Environ Chem 43:249-270. https://doi.org/10.1007/698-2015-411

Gonçalves JMS, Erzini K (1998) Feeding habits of the two-banded sea bream (Diplodus 492 vulgaris) and the Black Sea bream (Spondyliosoma cantharus) (Sparidae) from the south-west coast of Portugal. Cybium 22:245-254

Guidetti P (2006) Marine reserves reestablish lost predatory interactions and cause 495 community changes in rocky reefs. Ecol Appl 16:963-976. https://doi.org/10.1890/1051-0761(2006)016[0963:MRRLPI]2.0.CO;2

497 Guidetti P, Baiata P, Ballesteros E, et al (2014) Large-scale assessment of 498 Mediterranean marine protected areas effects on fish assemblages. PLoS One 499 9:e91841. https://doi.org/10.1371/journal.pone.0091841

500 Guidetti P, Milazzo M, Bussotti S, et al (2008) Italian marine reserve effectiveness: 501 does enforcement matter? Biol Conserv 141:699-709. 

https://doi.org/10.1016/j.biocon.2007.12.013

503 Guidetti P, Sala E (2007) Community-wide effects of marine reserves in the 504 Mediterranean Sea. Mar Ecol Prog Ser 335:43-56. https://doi.org/10.3354/meps335043

506 Hammann M, Wang G, Rickert E, et al (2013) Invasion success of the seaweed 507 Gracilaria vermiculophylla correlates with low palatibility. Mar Ecol Prog Ser 508 486:93-103. https://doi.org/10.3354/meps10361

509 Hyslop EJ (1980) Stomach contents analysis - a review of methods and their application. J Fish Biol 17:411-429. https://doi.org/10.1111/j.10958649.1980.tb02775.x

512 Ivlev VS (1961) Experimental ecology of the feeding of fishes. Yale University Press, $513 \quad$ New Haven, Connecticut, USA

514 Katsanevakis S, Tempera F, Teixeira H (2016) Mapping the impact of alien species on marine ecosystems: The Mediterranean Sea case study. Divers Distrib 22:694-707. https://doi.org/10.1111/ddi.12429

517 Katsanevakis S, Zenetos A, Belchior C, Cardoso AC (2013) Invading European Seas: 518 Assessing pathways of introduction of marine aliens. Ocean Coast Manag 76:6474. https://doi.org/10.1016/j.ocecoaman.2013.02.024

520 Kimbro DL, Cheng BS, Grosholz ED (2013) Biotic resistance in marine environments. $521 \quad$ Ecol Lett 16:821-833. https://doi.org/10.1111/ele.12106

522 Klein J, Verlaque M (2008) The Caulerpa racemosa invasion: A critical review. Mar $523 \quad$ Pollut Bull 56:205-225. https://doi.org/10.1016/j.marpolbul.2007.09.043

524 Leitão F, Santos MN, Monteiro CC (2007) Contribution of artificial reefs to the diet of 525 the white sea bream (Diplodus sargus). ICES J Mar Sci 64:473-478. 526 https://doi.org/10.1093/icesjms/fsm027 
527 Lloret J, Zaragoza N, Caballero D, et al (2008) Spearfishing pressure on fish 528 communities in rocky coastal habitats in a Mediterranean marine protected area. $529 \quad$ Fish Res 94:84-91. https://doi.org/10.1016/j.fishres.2008.07.002

530 Lyons DA, Scheibling RE (2008) Context-dependant survival of the invasive seaweed 531 Codium fragile ssp. tomentosoides in kelp bed and urchin barren habitats off Nova $532 \quad$ Scotia. Aquat Biol 2:17-27. https://doi.org/10.3354/ab00035

533 Macdonald JS, Green RH (1983) Redundancy of variables used to describe importance 534 of prey species in fish diets ( Bay of Fundy). Can J Fish Aquat Sci 40:635-637. 535 https://doi.org/10.1139/f83-083

536 March D, Alós J, Grau A, Palmer M (2011) Short-term residence and movement 537 patterns of the annular seabream Diplodus annularis in a temperate marine reserve. 538 Estuar Coast Shelf Sci 92:581-587. https://doi.org/10.1016/j.ecss.2011.02.015

539 Marco-Méndez C, Ferrero-Vicente LM, Prado P, Sánchez-Lizaso JL (2017) Epiphytes 540 and nutrient contents influence Sarpa salpa herbivory on Caulerpa spp. vs. 541 seagrass species in Mediterranean meadows. Estuar Coast Shelf Sci 184:54-66. $542 \quad$ https://doi.org/10.1016/j.ecss.2016.11.005

543 Micheli F, Benedetti-Cecchi L, Gambaccini S, et al (2005) Cascading human impacts, 544 marine protected areas, and the structure of Mediterranean reef assemblages. Ecol 545 Monogr 75:81-102. https://doi.org/10.1890/03-4058

546 Monteiro CA, Engelen AH, Santos ROP (2009) Macro- and mesoherbivores prefer 547 native seaweeds over the invasive brown seaweed Sargassum muticum: A potential 548 regulating role on invasions. Mar Biol 156:2505-2515. $549 \quad$ https://doi.org/10.1007/s00227-009-1275-1

550 Morales-Nin B, Moranta J, García C, et al (2005) The recreational fishery off Majorca 551 Island (western Mediterranean): some implications for coastal resource 
management.

ICES

Mar

Sci

$62: 727-739$. https://doi.org/10.1016/j.icesjms.2005.01.022

554 Mosquera I, Côté IM, Jennings S, Reynolds JD (2000) Conservation benefits of marine reserves for fish populations. Anim Conserv 3:321-332. https://doi.org/10.1017/S1367943000001049

Nejrup LB, Pedersen MF, Vinzent J (2012) Grazer avoidance may explain the invasiveness of the red alga Gracilaria vermiculophylla in Scandinavian waters. Mar Biol 159:1703-1712. https://doi.org/10.1007/s00227-012-1959-9

Nilssen KT, Lindstrøm U, Westgaard JI, et al (2019) Diet and prey consumption of grey seals (Halichoerus grypus) in Norway. Mar Biol Res 15:137-149. https://doi.org/10.1080/17451000.2019.1605182

563 Nizamuddin M (1991) The green marine algae of Libya. Koeltz Scientific Books

564 Oksanen J, Blanchet FG, Friendly M, et al (2018) Vegan: Community ecology package. R Packag. Version 2.4-6

Papacostas KJ, Rielly-Carroll EW, Georgian SE, et al (2017) Biological mechanisms of marine invasions. Mar Ecol Prog Ser 565:251-268. https://doi.org/10.3354/meps12001

569 Paul V, Arthur KE, Ritson-Williams R, et al (2007) Chemical defenses: from compounds to communities. Biol Bull 213:226-251. https://doi.org/213/3/226 [pii]

571 Piazzi L, Ceccherelli G, Cinelli F (2001) Threat to macroalgal diversity: effects of the 572 introduced green alga Caulerpa racemosa in the Mediterranean. Mar Ecol Prog Ser 210:149-159. https://doi.org/10.3354/meps210149

574 Piazzi L, Meinesz A, Verlaque M, et al (2005) Invasion of Caulerpa racemosa var. 575 cylindracea (Caulerpales, Chlorophyta) in the Mediterranean Sea: An assessment 576 of the spread. Cryptogam Algol 26:189-202 
577 Pita C, Gamito S, Erzini K (2002) Feeding habits of the gilthead seabream (Sparus

578

579

580

581

582

583

584

585

586

587

588

589

590

591

592

593

594

595

596

597

598

599

600

601 aurata) from the Ria Formosa (southern Portugal) as compared to the back seabream (Spondyliosoma cantharus) and the annular seabream (Diplodus annularis). J Appl Ichthyol 18:81-86. https://doi.org/10.1046/j.1439$0426.2002 .00336 . x$

Preti A, Smith SE, Ramon DA (2001) Feeding habits of the common thresher shark (Alopias vulpinus) sampled from the California-based drift gill net fishery, 19981999. Calif Coop Ocean Fish Investig Reports 42:145-152

R Core Team (2018) R: a language and environment for statistical computing

Reñones O, Moranta J, Coll J, Morales-Nin B (1997) Rocky bottom fish communities of Cabrera Archipelago National Park (Mallorca, Western Mediterranean). Sci Mar $61: 495-506$

Rogers PJ, Huveneers C, Page B, et al (2012) A quantitative comparison of the diets of sympatric pelagic sharks in the gulf and shelf ecosystems off southern Australia. ICES J Mar Sci 69:1382-1393. https://doi.org/10.2307/4451315

Ruitton S, Verlaque M, Aubin G, Boudouresque CF (2006) Grazing on Caulerpa racemosa var. cylindracea (Caulerpales, Chlorophyta) in the Mediterranean Sea by herbivorous fishes and sea urchins. Vie Milieu 56:33-41

Ruitton S, Verlaque M, Boudouresque CF (2005) Seasonal changes of the introduced Caulerpa racemosa var. cylindracea (Caulerpales, Chlorophyta) at the northwest limit of its Mediterranean range. Aquat Bot 82:55-70. https://doi.org/10.1016/j.aquabot.2005.02.008

Sala E (2004) The past and present topology and structure of Mediterranean subtidal rocky-shore food webs. Ecosystems 7:333-340. https://doi.org/10.1007/s10021003-0241-X 
602 Sala E, Ballesteros E (1997) Partitioning of space and food resources by three fish of 603 the genus Diplodus (Sparidae) in a Mediterranean rocky infralittoral ecosystem. 604 Mar Ecol Prog Ser 152:273-283. https://doi.org/10.3354/meps152273

605 Sala E, Ballesteros E, Dendrinos P, et al (2012) The structure of Mediterranean rocky 606 reef ecosystems across environmental and human gradients, and conservation 607 implications. PLoS One 7:e32742. https://doi.org/10.1371/journal.pone.0032742

608 Sala E, Boudouresque CF, Harmelin-Vivien M (1998) Fishing, trophic cascades, and 609 the structure of algal assemblages: Evaluation of an old but untested paradigm.

611 Oikos 82:425-439. https://doi.org/10.2307/3546364

Sánchez-Jerez P, Gillanders BM, Rodríguez-Ruiz S, Ramos-Esplá AA (2002) Effect of an artificial reef in Posidonia meadows on fish assemblage and diet of Diplodus annularis. ICES J Mar Sci 59:59-68. https://doi.org/10.1006/jmsc.2002.1213

Sant N, Chappuis E, Rodríguez-Prieto C, et al (2017) Cost-benefit of three different methods for studying Mediterranean rocky benthic assemblages. Sci Mar 81:129. https://doi.org/10.3989/scimar.04463.04a

Schaffelke B, Hewitt CL (2008) Impacts of introduced seaweeds. Seaweed Invasions A Synth Ecol Econ Leg Imp 50:77-97. https://doi.org/10.1515/9783110211344

Schaffelke B, Smith JE, Hewitt CL (2006) Introduced macroalgae - A growing concern. J Appl Phycol 18:529-541. https://doi.org/10.1007/s10811-006-9074-2

Scheibling RE, Anthony SX (2001) Feeding, growth and reproduction of sea urchins (Strongylocentrotus droebachiensis) on single and mixed diets of kelp (Laminaria spp.) and the invasive alga Codium fragile ssp. tomentosoides. Mar Biol 139:139146. https://doi.org/10.1007/s002270100567

Seebens H, Gastner MT, Blasius B (2013) The risk of marine bioinvasion caused by global shipping. Ecol Lett 16:782-790. https://doi.org/10.1111/ele.12111 
627 Stachowicz JJ, Terwin JR, Whitlatch RB, Osman RW (2002) Linking climate change

628 and biological invasions: ocean warming facilitates nonindigenous species invasions. Proc Natl Acad Sci U S A 99:15497-15500. https://doi.org/10.1073/pnas.242437499

631 Steinarsdóttir MB, Ingólfsson A, Ólafsson E (2009) Trophic relationships on a fucoid 632 shore in south-western Iceland as revealed by stable isotope analyses, laboratory experiments, field observations and gut analyses. J Sea Res 61:206-215. https://doi.org/10.1016/j.seares.2008.11.004

Stimson J, Larned ST, Conklin E (2001) Effects of herbivory, nutrient levels, and

Terlizzi A, Felline S, Lionetto MG, et al (2011) Detrimental physiological effects of the invasive alga Caulerpa racemosa on the Mediterranean white seabream Diplodus

642 Thomsen MS, Wernberg T, South PM, Schiel DR (2016) Non-native seaweeds drive

Tomas F, Box A, Terrados J (2011a) Effects of invasive seaweeds on feeding 650 preference and performance of a keystone Mediterranean herbivore. Biol Invasions 13:1559-1570. https://doi.org/10.1007/s10530-010-9913-6 
652 Tomas F, Cebrian E, Ballesteros E (2011b) Differential herbivory of invasive algae by

653 native fish in the Mediterranean Sea. Estuar Coast Shelf Sci 92:27-34. $654 \quad$ https://doi.org/10.1016/j.ecss.2010.12.004

655 Tripp-Valdez A, Galván-Magaña F, Ortega-García S (2015) Food sources of common 656 dolphinfish (Coryphaena hippurus) based on stomach content and stable isotopes 657 analyses. J Mar Biol Assoc United Kingdom 95:579-591. $658 \quad$ https://doi.org/10.1017/S0025315414001842

659 Trowbridge CD, Todd CD (1999) The familiar is exotic: I. Codium fragile ssp. 660 atlanticum on Scottish rocky intertidal shores. Bot J Scotl 51:139-159. 661 https://doi.org/10.1080/03746609908684932

662 Vermeij MJA, Smith TB, Dailer ML, Smith CM (2009) Release from native herbivores 663 facilitates the persistence of invasive marine algae: A biogeographical comparison 664 of the relative contribution of nutrients and herbivory to invasion success. Biol 665 Invasions 11:1463-1474. https://doi.org/10.1007/s10530-008-9354-7

666 Wikström SA, Steinarsdóttir MB, Kautsky L, Pavia H (2006) Increased chemical 667 resistance explains low herbivore colonization of introduced seaweed. Oecologia $668 \quad$ 148:593-601. https://doi.org/10.1007/s00442-006-0407-2

669 Williams SL, Smith JE (2007) A global review of the distribution, taxonomy, and 670 impacts of introduced seaweeds. Annu Rev Ecol Evol Syst 38:327-359. 671 https://doi.org/10.1146/annurev.ecolsys.38.091206.095543 


\section{Tables}

674 Table 1. Summary of the stomach content data for each fish species.

\begin{tabular}{|c|c|c|c|}
\hline D. annularis & Mean \pm S.E. $(\%)$ & D. sargus & Mean \pm S.E. $(\%)$ \\
\hline Algal content & $30.41 \pm 13.58$ & Algal content & $18.68 \pm 3.84$ \\
\hline Caulerpa cylindracea & $25.73 \pm 11.80$ & Caulerpa cylindracea & $3.56 \pm 0.96$ \\
\hline Plants & $0.26 \pm 0.21$ & Plants & $9.36 \pm 2.84$ \\
\hline Animal content & $43.28 \pm 16.00$ & Animal content & $48.31 \pm 5.53$ \\
\hline Detritus & $26.05 \pm 15.03$ & Detritus & $23.64 \pm 5.08$ \\
\hline D. vulgaris & Mean \pm S.E. $(\%)$ & S. cantharus & Mean \pm S.E. $(\%)$ \\
\hline Algal content & $8.80 \pm 6.91$ & Algal content & $7.03 \pm 2.50$ \\
\hline Caulerpa cylindracea & 0 & Caulerpa cylindracea & $5.15 \pm 1.94$ \\
\hline Plants & $0.29 \pm 0.25$ & Plants & $0.40 \pm 0.26$ \\
\hline Animal content & $54.75 \pm 12.30$ & Animal content & $14.10 \pm 4.81$ \\
\hline Detritus & $36.16 \pm 11.14$ & Organic detritus & $78.47 \pm 5.12$ \\
\hline
\end{tabular}

The ingested food items are grouped into categories and the values given are mean percentages \pm S.E. for each fish species.

675 Table 2. Results of the ANOSIM and the pairwise comparisons between fish species to detect diet

676 similarities between species under 999 permutations.

\begin{tabular}{cccc}
\hline Test & Fish species & R Statistic & Significance \\
\hline Global test & All species & 0.201 & $0.001^{*}$ \\
\hline \multirow{3}{*}{ Pairwise test } & D. annularis vs D. sargus & 0.184 & 0.306 \\
& D. annularis vs D. vulgaris & 0.398 & $0.006^{*}$ \\
& D. annularis vs $S$. cantharus & 0.625 & $0.006^{*}$ \\
& D. sargus vs D. vulgaris & 0.156 & 0.102 \\
& D. sargus vs $S$. cantharus & 0.171 & $0.012^{*}$ \\
& D. vulgaris vs $S$. cantharus & 0.473 & $0.006^{*}$ \\
\hline
\end{tabular}

The asterisk $(*)$ indicates statistical significance (p-value $<0.05)$. 
677 Table 3. Results of the SIMPER analysis to detect the most important prey items contributing to the diet 678 dissimilarities between fish species.

\begin{tabular}{|c|c|c|}
\hline Fish species & Item & $\begin{array}{c}\text { Cumulative contribution } \\
\text { to dissimilarities }\end{array}$ \\
\hline \multirow{4}{*}{ D. annularis vs. D. sargus } & Organic detritus & 0.187 \\
\hline & Caulerpa cylindracea & 0.327 \\
\hline & Eggs & 0.466 \\
\hline & Organic detritus & 0.215 \\
\hline \multirow[t]{2}{*}{ D. annularis vs. D. vulgaris } & Caulerpa cylindracea & 0.359 \\
\hline & Eggs & 0.495 \\
\hline \multirow{4}{*}{ D. annularis vs. S. cantharus } & Organic detritus & 0.399 \\
\hline & Caulerpa cylindracea & 0.568 \\
\hline & Eggs & 0.732 \\
\hline & Organic detritus & 0.214 \\
\hline \multirow[t]{2}{*}{ D. sargus vs. D. vulgaris } & Gasteropoda & 0.394 \\
\hline & Crustacea & 0.518 \\
\hline \multirow{4}{*}{ D. sargus vs. S. cantharus } & Organic detritus & 0.394 \\
\hline & Gasteropoda & 0.503 \\
\hline & Non-identified invertebrate & 0.554 \\
\hline & Organic detritus & 0.382 \\
\hline \multirow[t]{2}{*}{ D. vulgaris vs. S. cantharus } & Gasteropoda & 0.548 \\
\hline & Crustacea & 0.695 \\
\hline
\end{tabular}

Only the 3 most important food items are shown. 
679 Table 4. Mean \pm S.E. values for Ivlev's electivity Index (E), as a measure of the electivity of the four 680 sparid fish species studied towards the invasive alga C. cylindracea.

\begin{tabular}{lr}
\hline \multicolumn{2}{c}{$\mathrm{E}_{\text {Caulerpa }}$} \\
\hline D. annularis & $-0.52 \pm 0.18$ \\
D. sargus & $-0.90 \pm 0.02$ \\
D. vulgaris & -1 \\
S. cantharus & $-0.86 \pm 0.05$ \\
\hline
\end{tabular}

An E value approaching -1 indicates that the food item is avoided; whereas an E value approaching 1 indicates the species only feeds on that item. 


\section{$681 \quad$ Figures}

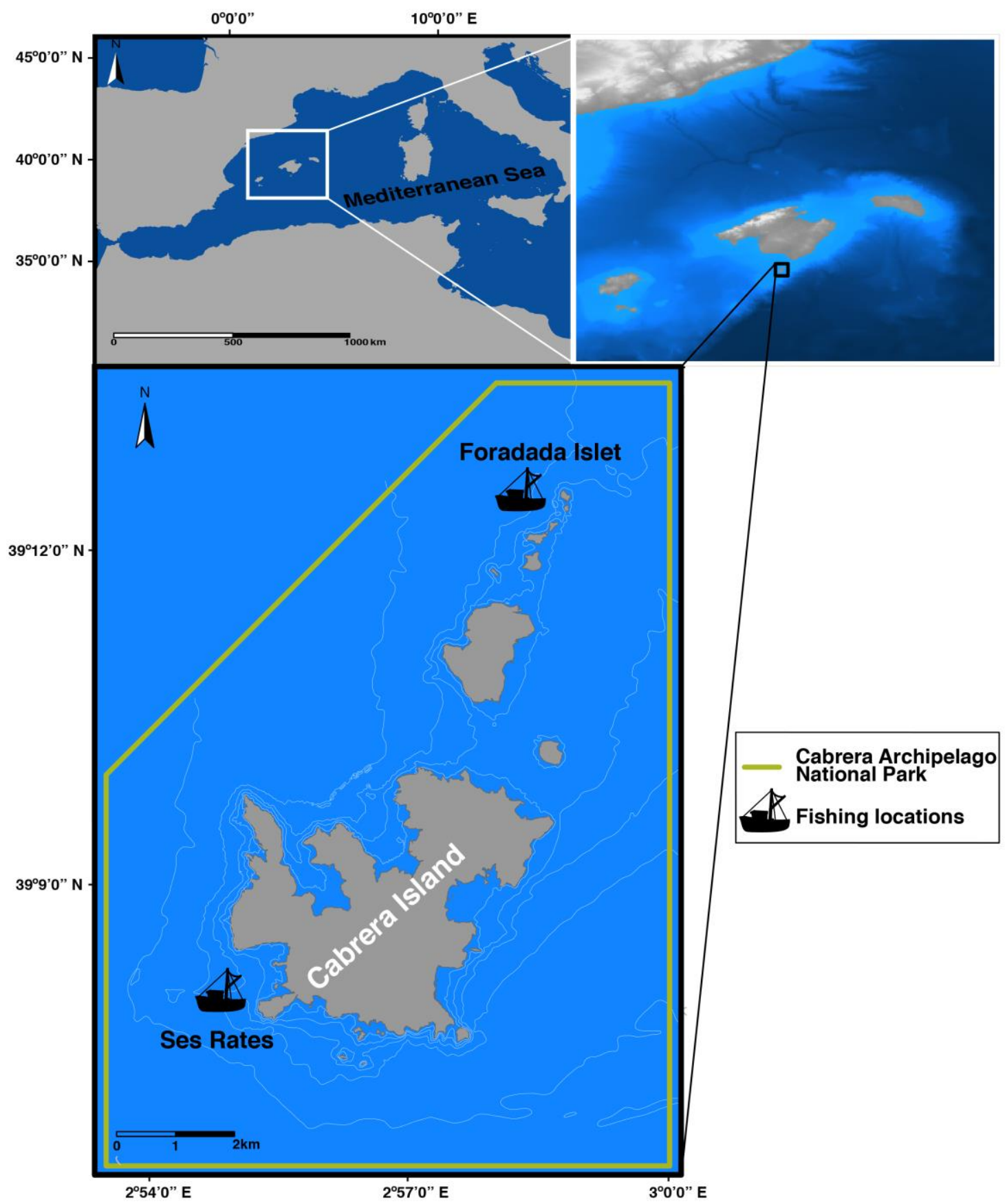

682 Fig. 1: Map of Cabrera Archipelago with the locations where the fishing was done. Shapefile for the

683 Mediterranean Sea downloaded from www.naturalearthdata.com and for the Cabrera Archipelago

684 National Park from www.miteco.gob.es. 


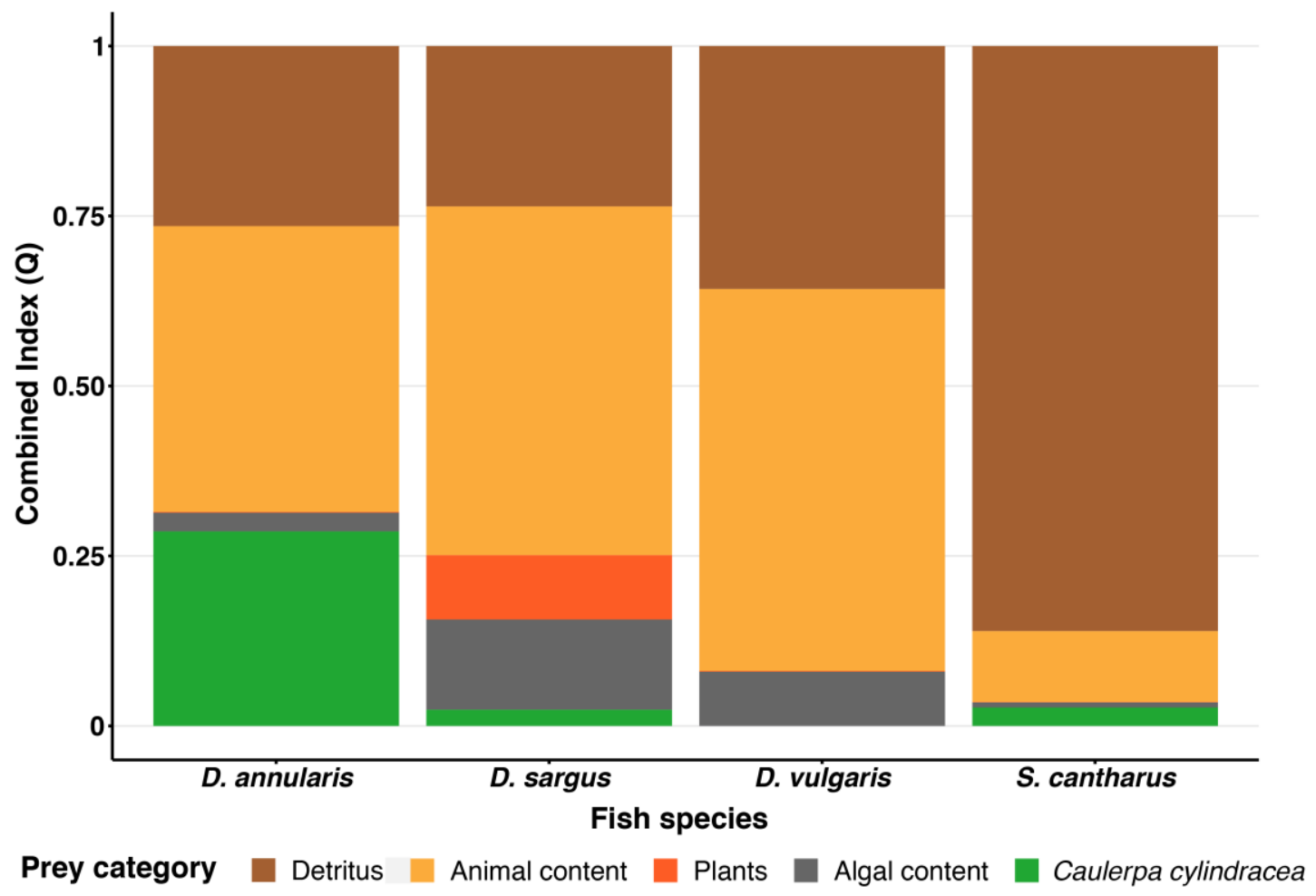

685 Fig. 2. Combined Index (Q) for each fish species. Each color represents one of five prey item categories 686 (Detritus, Animals, Plants, Algae and Caulerpa). 

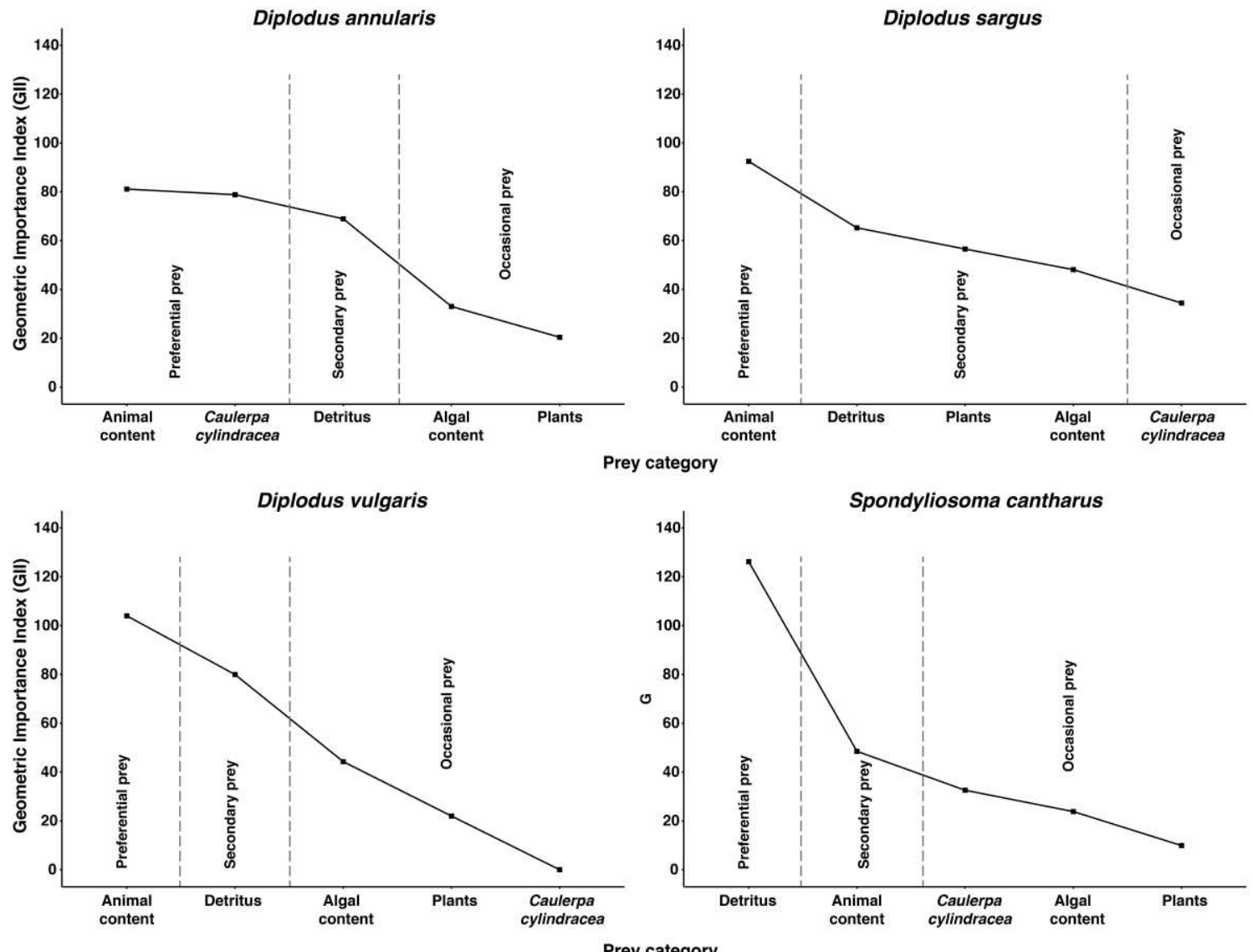

687 Fig. 3. Geometric Importance Index (GII) for each fish species. Prey items are classified as: "Preferential 688 prey", "Secondary prey" or "Occasional prey" according to their relative importance to the diet of each 689 fish species. The line connecting the points was added to help interpretation of the figure. 


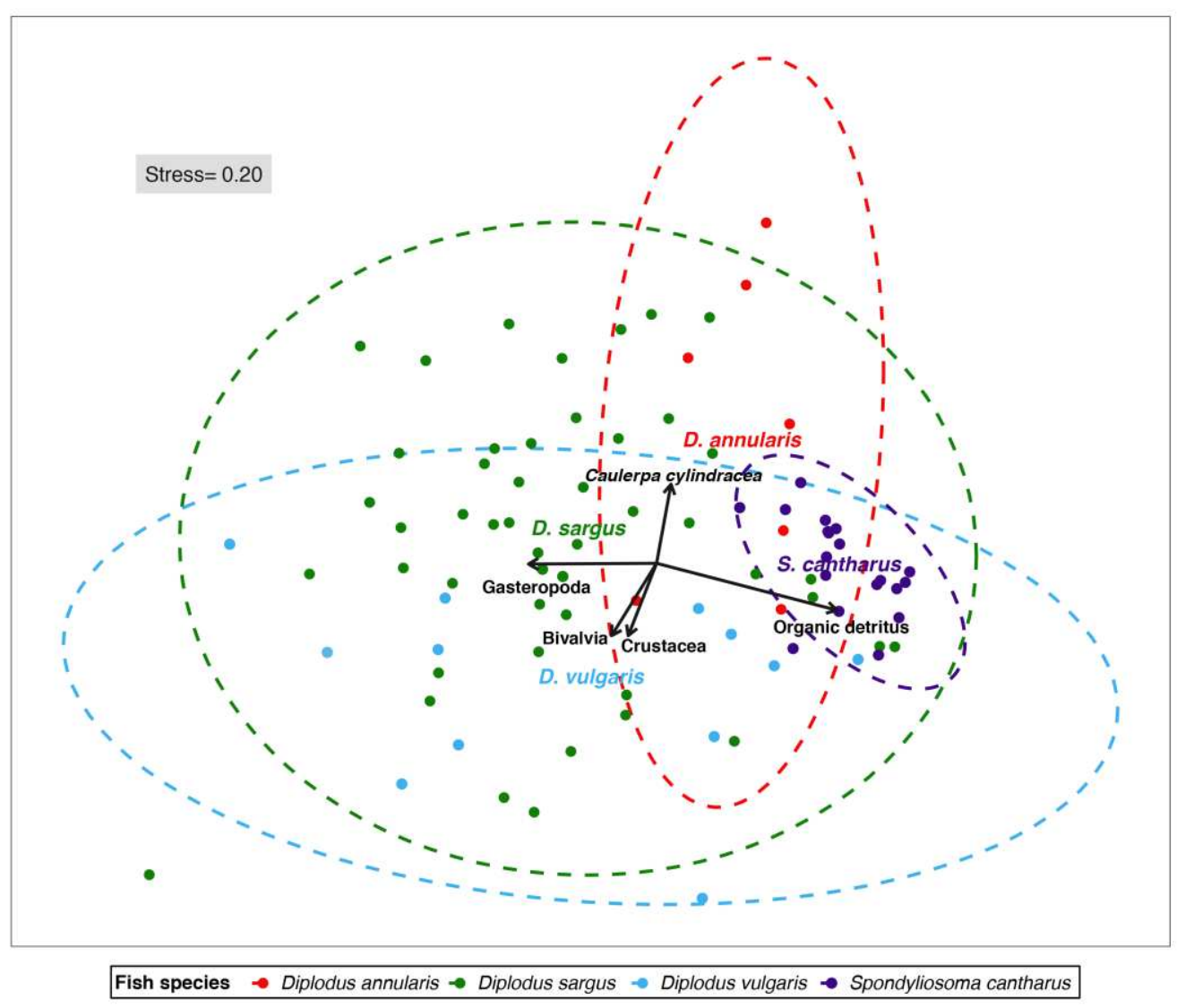

690 Fig. 4. Non-metric MDS for the stomach content of the different fish species. Each ellipse surrounds the 691 points for one fish species and the black arrows represent the most significant food items determining the 692 ordination. For these variables, only the ones with a p-value lower or equal to 0.001 were represented.

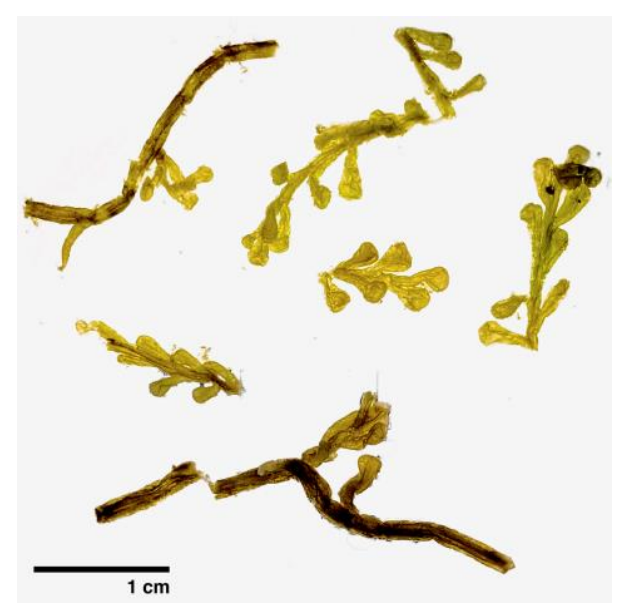

693 Fig. 5. Macroscopic view of Caulerpa cylindracea fragments, as found in the stomach contents. 


\section{Figures}

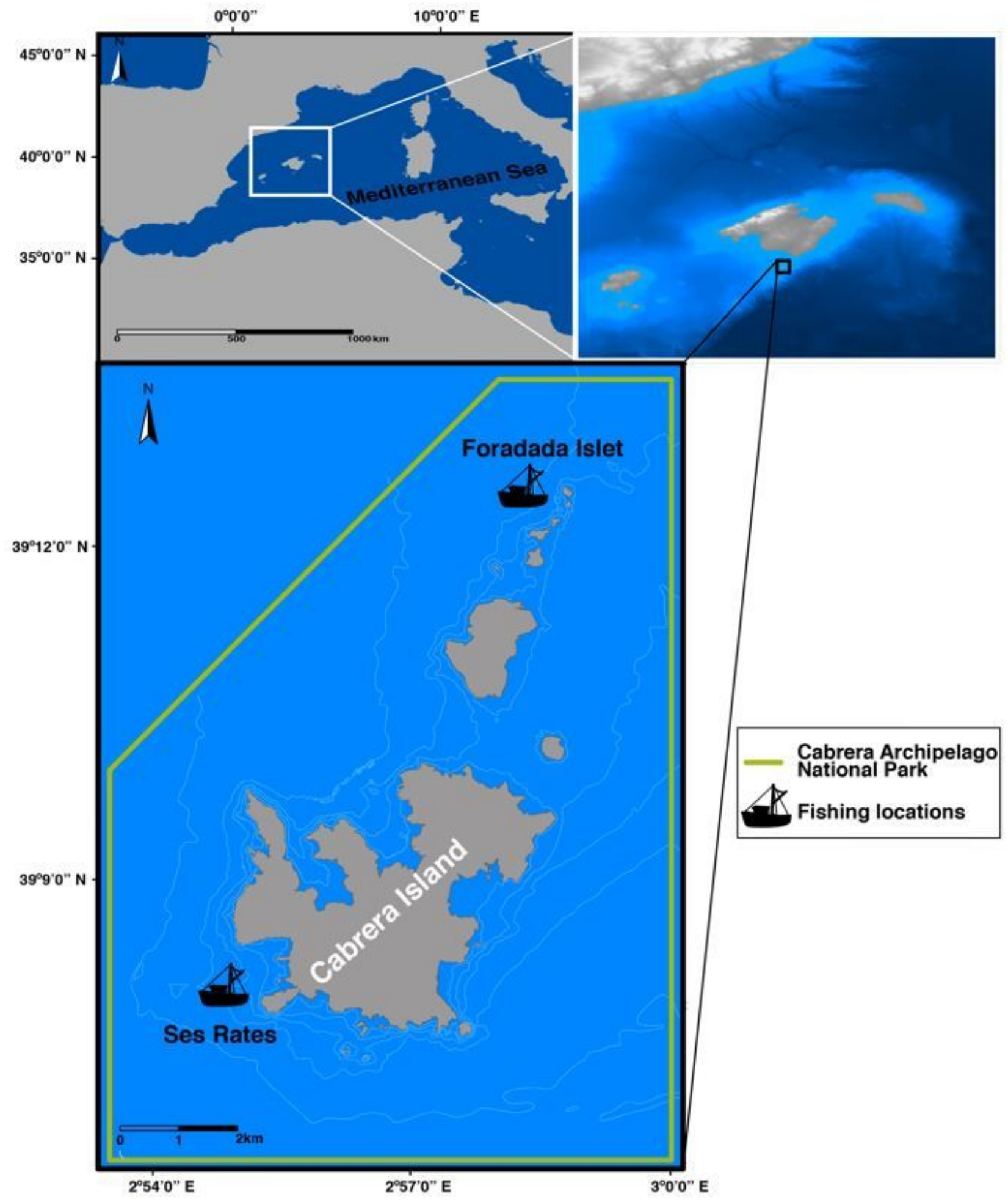

\section{Figure 1}

Map of Cabrera Archipelago with the locations where the fishing was done. Shapefile for the Mediterranean Sea downloaded from www.naturalearthdata.com and for the Cabrera Archipelago National Park from www.miteco.gob.es. Note: The designations employed and the presentation of the 
material on this map do not imply the expression of any opinion whatsoever on the part of Research Square concerning the legal status of any country, territory, city or area or of its authorities, or concerning the delimitation of its frontiers or boundaries. This map has been provided by the authors.

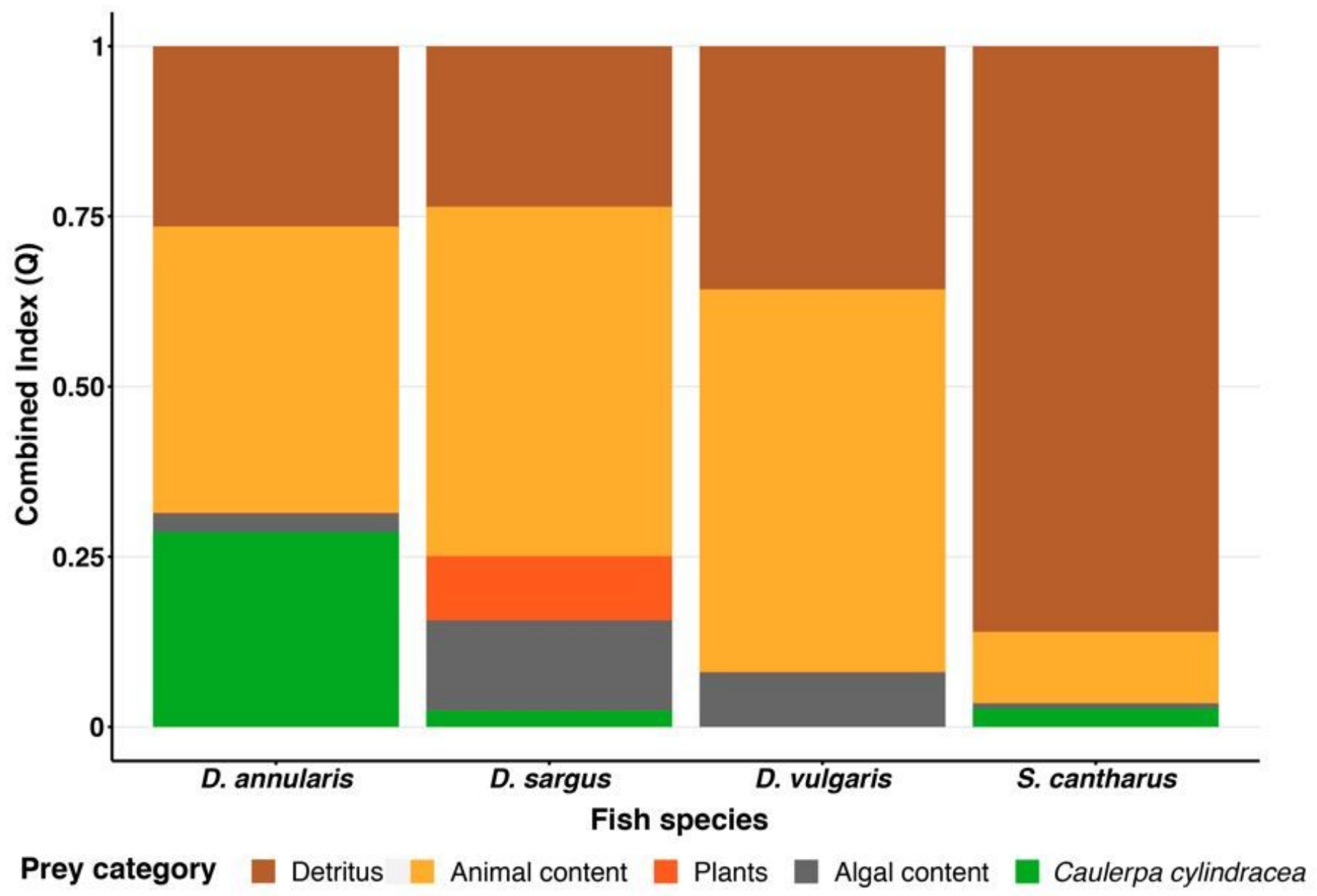

\section{Figure 2}

Combined Index (Q) for each fish species. Each color represents one of five prey item categories (Detritus, Animals, Plants, Algae and Caulerpa). 

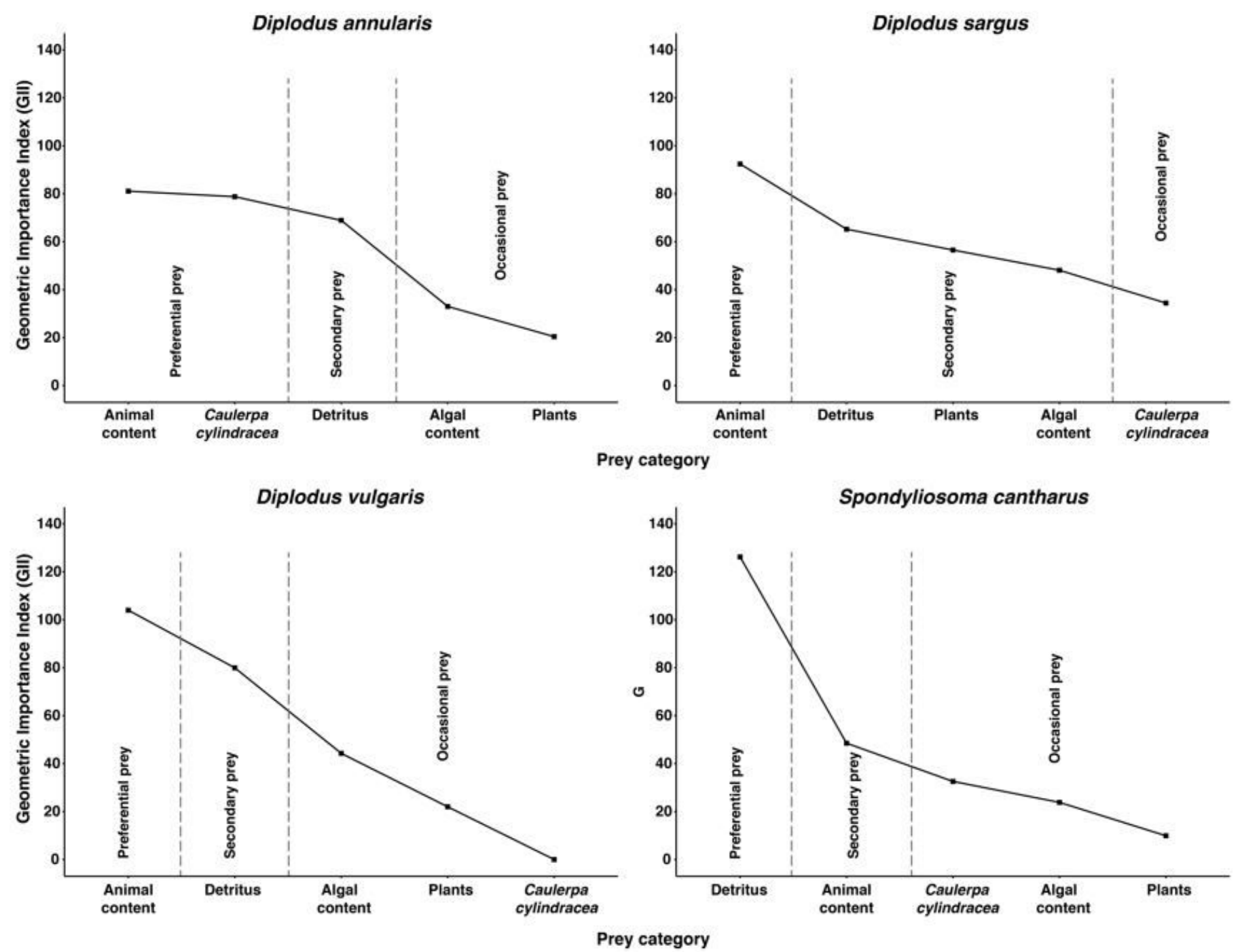

Figure 3

Geometric Importance Index (GII) for each fish species. Prey items are classified as: "Preferential prey", "Secondary prey" or "Occasional prey" according to their relative importance to the diet of each fish species. The line connecting the points was added to help interpretation of the figure. 


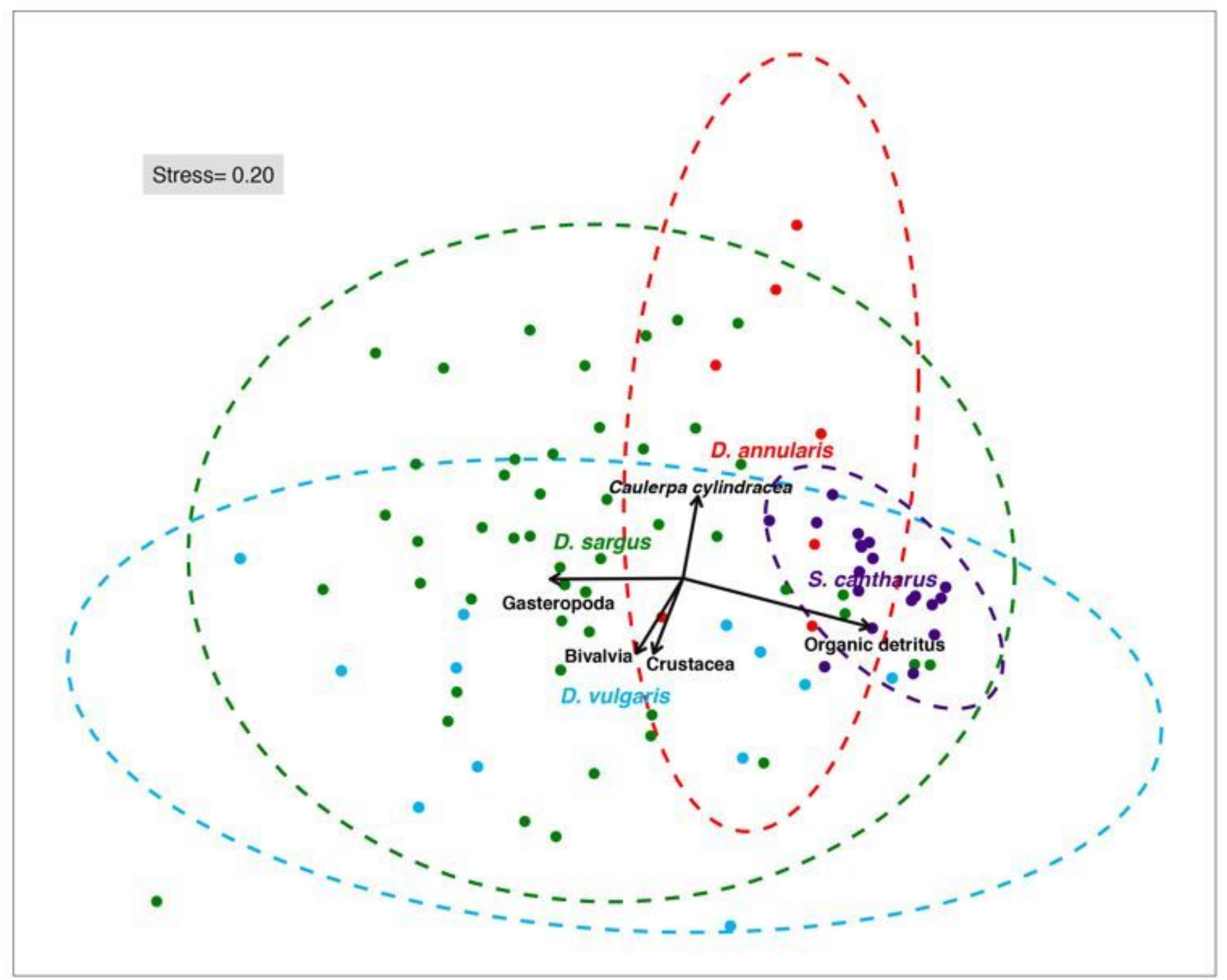

Fish species $\rightarrow$ Diplodus annularis $\rightarrow$ Diplodus sargus $\bullet$ Diplodus vulgaris $\bullet$ Spondyliosoma cantharus

\section{Figure 4}

Non-metric MDS for the stomach content of the different fish species. Each ellipse surrounds the points for one fish species and the black arrows represent the most significant food items determining the ordination. For these variables, only the ones with a p-value lower or equal to 0.001 were represented. 


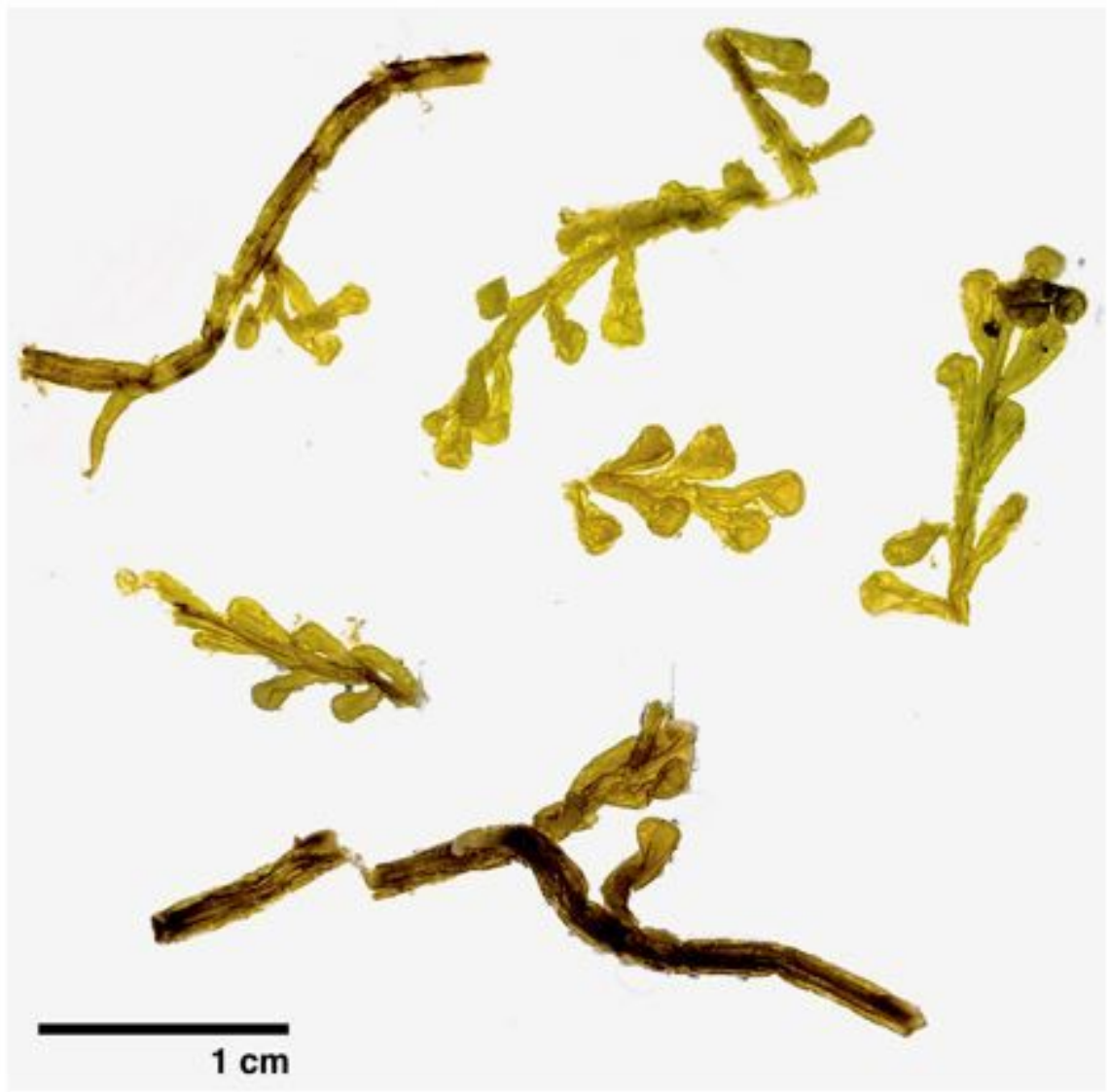

Figure 5

Macroscopic view of Caulerpa cylindracea fragments, as found in the stomach contents.

\section{Supplementary Files}

This is a list of supplementary files associated with this preprint. Click to download.

- JorgeSantamariaSupportinglnformation.docx 